\title{
Diagenetic signals archived in calcitic glendonite of the Ediacaran Doushantuo Formation, South China
}

\author{
ZHOU WANG ${ }^{1}$, JiASHENG WANG ${ }^{1}$, SHUHAi XIAO ${ }^{2}$
}

${ }^{1}$ State Key Laboratory of Biogeology and Environmental Geology \& College of Marine Science and Technology, China University of Geosciences, Wuhan 430074, PR

China (Z. Wang: wungchou@qq.com; J. Wang: jswang@cug.edu.cn)

${ }^{2}$ Department of Geosciences, Virginia Tech, Blacksburg, VA 24061, USA (S. Xiao: xiao@vt.edu)

Calcitic glendonites in the Ediacaran Doushantuo (DST) Formation are pseudomorphs of precursor ikaite, and preserve the diagenetic history of the DST Fm. We analysed $\mathrm{C}, \mathrm{O}, \mathrm{Sr}$, and carbonate clumped isotope compositions $\left(\Delta_{47}\right)$ of DST glendonites from two drill cores. Sparry and blocky calcite in DST glendonites yielded variable and sometimes extremely negative $\delta^{13} \mathrm{C}$ values, which are negatively correlated with $\delta^{18} \mathrm{O}$ values. A thermal history with temperatures of 100 $170^{\circ} \mathrm{C}$ is inferred from the $\Delta_{47}$ thermometry. The $\Delta_{47}$ temperatures of DST glendonites are compatible with the upper limit of $\Delta_{47}$-temperatures from the EN3 unit (Loyd et al., 2015) that overlies the glendonite-bearing strata, which is characterized by the EP1 feature. DST glendonite may have been altered (e.g., recrystallization) during burial diagenesis. $\mathrm{Sr}$ isotopes of DST glendonite, particularly those of extremely ${ }^{13} \mathrm{C}$-depleted samples, deviate from ${ }^{87} \mathrm{Sr} /{ }^{86} \mathrm{Sr}$ ratios of bulk dolostone of DST Member II (EP1) (Sawaki et al., 2010) that is correlated with the glendonite-bearing strata. This deviation is further evidence for diagenetic alteration of DST glendonite. 